\title{
交差点におけるドライバーへの音声警告提示時間の基礎的検討
}

\author{
専門会員 阿 山みよし(宇都宮大学大学院) 非会員 加 藤 崇 史 (宇都宮大学大学院) \\ 非会員 漆 畑 直 紀 (宇都宮大学大学院) \\ 非会員 山 口亨（東京都立科学技術大学大学院） 非会員 大 橋 邦 博（東京都立科学技術大学大学院）
}

\section{Study on Timing of Voice Warning at Crossings}

Fellow Member Miyoshi Ayama (Utsunomiya University, Graduate School),

Non-Member Takashi Kato (Utsunomiya University, Graduate School),

Non-Member Naoki Urushibata (Utsunomiya University, Graduate School),

Non-Member Toru Yamaguchi (Tokyo Metropolitan Institute of Technology, Graduate School) and

Non-Member Kunihiro Ohashi (Tokyo Metropolitan Institute of Technology, Graduate School)

\begin{abstract}
We developed prototype of a new system to warn drivers about unseen pedestrians or bicycles at intersections. We carried out two experiments using a simple simulator system and one field experiment. In all the experiments, a warning voice was issued to the driver at various times before making a left or right turn. The drivers were asked to evaluate the timing of the warning subjectively. We also monitored accelerator and break pedal activity. The results showed that the best timing is 3 or 4 seconds before entering the intersection. The effects of the warning on the deceleration and breaking showed large individual differences and depended on the experimental conditions.
\end{abstract}

KEYWORDS : warning system, intersection, proper timing, driver's attention

\section{1.はじめに}

わが国の自動車保有率は年々増加し, 死亡者数は減少傾向にある ものの依然交通事故数は增加の傾向にある ${ }^{\mathrm{i})}$. ITS (Intelligent Transport Systems)の進展に伴いドライバーに対する各種の情報提 供, 即ち各種の警報, 効率的な走行経路案内, 娛楽情報などの車内 情報提示が実現しつつある.このような情報提示システムが開発さ れていく中で，どのような情報を適切にドライバーに提示すべきか が改めて問い直されている ${ }^{233)}$.そこで, 運転中に提供された情報 の処理は新たな認知負荷となることから, 人の情報処理容量を考慮 して, 主タスクである運転作業に影響を及ぼさないよう情報量とそ

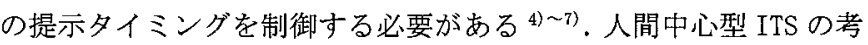
え方である.このような背景から本研究では, 交差点に抢ける進入 物探知とドライバーへの警告システムに注目し, 人間の認知特性に 適合し且つ工学的に高効率な情報提示設計への基礎的知見を得て, 適切な警告提示方法及び提示時閒を検討することを目的とする.

\section{2. 交差点における探知警告システム}

自動車に搭載された無線受信システムが，交差点に設けた情報送 信システムの範囲内に進入した場合に, 交差点付近の自動車側から 確認されない歩行者などの状況を運転者に情報提示するシステム

\footnotetext{
本論文の一部は平成 15 年照明学会第 36 回全国大会, 平成 16 年シンポジウム「ケータ イ・カーナビの利用性と人間工学」にて発表した
}

（図 1）のプロトタイプを作成した，自動車および歩行者の交差 点端点からの距離を測定するために, カメラ 2 台を利用したステ レオ視と対象物体の色検出機能を備えたシステム（I-SPACE）2組 を用いた。自動車に搭載された無線受信システムが，交差点に設 けられた情報送受信システムの範囲内に進入した場合に, 交差点 付近の自動車側から確認されない歩行者や物体の状況を, 運転者 に警告するシステムである ${ }^{8)}$.

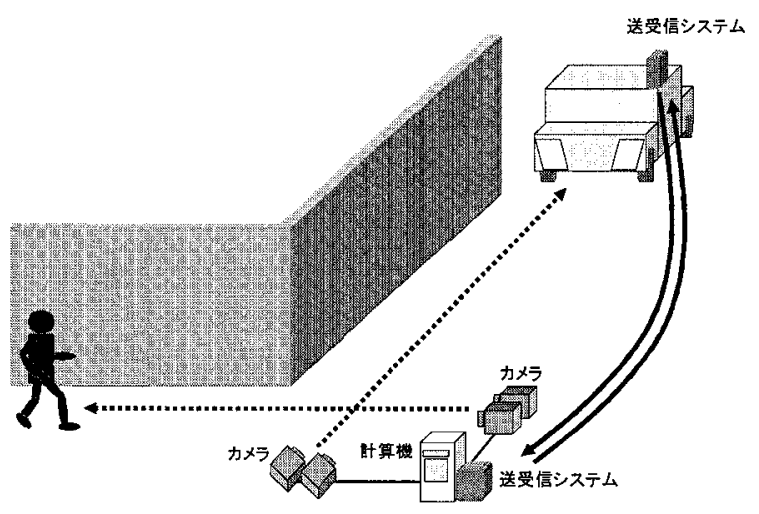

図 1 妨害物探知警告提示システム

Fig.1 Detection and warning system at the crossing. 


\section{3. 実験 1}

見通しの悪い交差点を自動車が右折又は左折し，曲がった途端に 歩行者を発見するという状況を設定し，そのシーンを撮影した。撮 影場所を図 2 に示す。その映像をスクリーン上に投影して警告タイ ミングを評価する室内実験と，その場所で自動車を運転して同様の 評価を行うフィールド実験を行った。

\section{1 室内実験}

\subsection{1 映像及び音声刺激}

室内実験用映像の撮影車両は図 3 に示寸電動スクーター（以後, 車と表記）を用いた. 交差点に車が約 $20 \mathrm{~km} / \mathrm{h} の 一$ 定速度で進入し て右折又は左折し終えるまでの映像を運転者の視線に合わせるよ うにして DV カメラで撮影した。 車が右折又は左折した直後の歩行 者の位膡を 3 パターン（交差点の端から $1.4 \mathrm{~m} \sim 2 \mathrm{~m}, 4 \mathrm{~m} \sim 4.6 \mathrm{~m}, 7.4 \mathrm{~m}$ 〜 $8 \mathrm{~m}$ の範囲）設定し，歩行者不在の映像も撮影した. 1 つの映像は 平均約 25 秒である. その各々について，「人が来ます」という約 0.5 秒の音声情報車が交差点端点に進入する直前基準 0 秒として, $0,2 ， 3 ， 4 ， 6$ 秒前の 5 種のタイミングで提示した。運転操作に関 するコントロール実験として, 歩行者不在映像（音声提示なし）を 用いて同様の運転操作を行ってもらった. 映像の種類は歩行者あり で 90 映像, 歩行者なしで 6 映像, 合計 96 映像を実験映像として用 W.

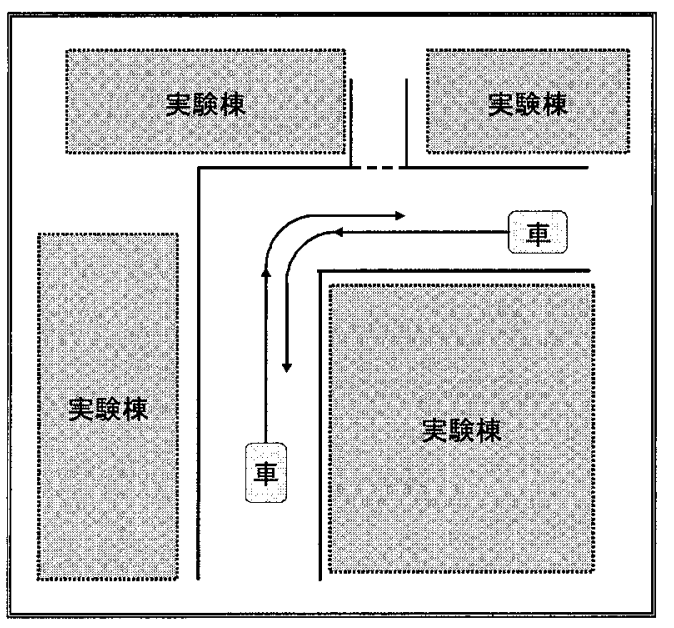

図 2 実験 1 における撮影場所

Fig.2 Filming place for experiment 1.

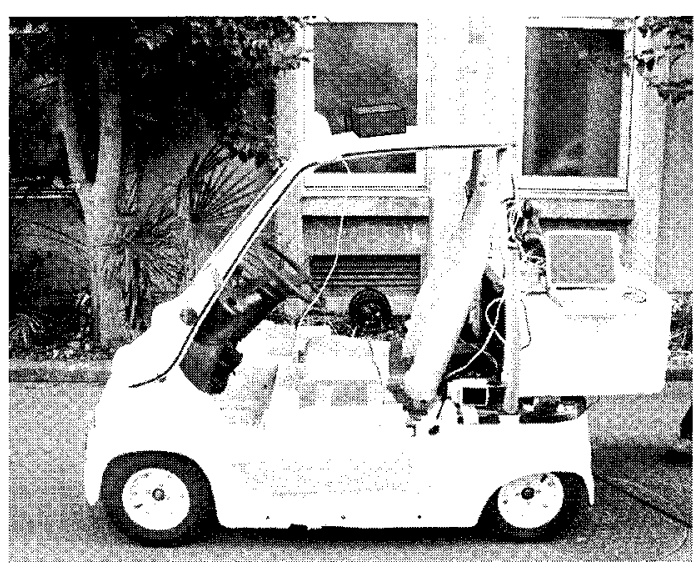

図 3 電動スクーター

Fig.3 Electric scooter.

\section{1 .2 実験装置及び手順}

図 4 に実験装置を示す．被験者には乗用車を模擬した運転席に 座ってもらい, 前方に実験映像を映すスクリーンを 3 面配置し, 後方上部の 3 ヶ所にプロジェクタを 3 台設置した. 実験 1 では中 央のプロジェクタとスクリーンのみを使用した．また，後方両脇 に臨場感を出すための環境音及び提示音声が出力される 2 台のス ピーカーを設置した.

被験者には映像に合わせて運転操作をするよう指示し, 右折又 は左折して停止後, 音声情報のタイミングについて主観評価(遅 い, やや遅い, 適度, やや早い，早いを行ってもらった。同時 にアクセル，ブレーキの踏み角のデータを記録した。被験者は運 転免許保持の視力・聴覚正常な 20 代男性 9 名, 女性 1 名, 計 10 名に行ってもらった. 各被験者において試行数は 96 回で, 1 セッ ション 12 映像である. 実験映像をランダムな順で組み合わせて 提示した。

\section{2 フィールド害験}

フィールド実験では，実験映像を撮影したのと同一の場所でほ ぼ同一の状況を再現し, 被験者に電動スクーターを運転させて右 折又は左折してもらった. 右折又は左折し停止した後に音声情報 提示のタイミングの主観評価を行った。同時にステアリング角度 と速度変化も記録した.フィールド実験では多数の試行はできな いので, 歩行者の位置は交差点の端から約 $4 \mathrm{~m} に$ 固定した。被験 者 1 名につき右折 5 試行, 左折 5 試行, 計 10 試行である. 被験 者は運転免許保持の視力・聴覚正常な 20 代男性 7 名, 女性 1 名, 計 8 名に行ってもらった.

\section{3 結果}

図 5 に室内実験の右左折時におうける「適度」評価の割合を示す。 縦軸は各々の音声提示時閒条件において, 10 名 $\times 6$ 試行 $=60$ 回の 忘答中の「適度」回答の割合である、横軸は音声を提示した時間 を表している. カテゴリとしてグラフでは $0,-2,-3,-4,-6$ と している. 異なる棒と図中の数值は歩行者の交差点からの位置で ある.これにより，歩行者が交差点に近い状況（平均 $2.62 \mathrm{~m} ）$ で は 4 秒前, 中位の状況 (平均 4.18m) では 3 秒前, 遠い状況（平 均 $8.00 \mathrm{~m})$ では 2 秒前での音声提示が良いことが分かる. 歩行者 の位置により適度評価のピーク位置が変化していることから, 適 度評価には何か一定值となる要因があると考えられる。

そこで,「適度」と評価されたデータ群において, 音声提示か ら歩行者の脇を通過するまでの時閒の分布を調べた。その結果を 図6に示す。

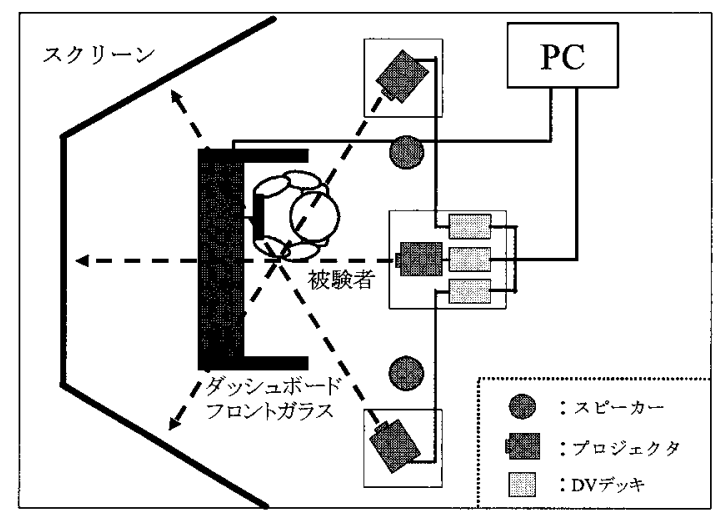

図 4 実験装置の概略図

Fig.4 Experimental apparatus. 


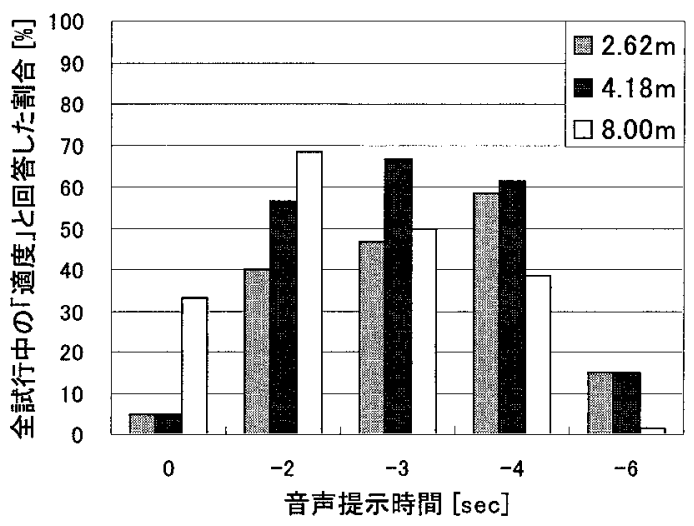

図 5 室内実験における「適度」評価の分布

Fig.5 Results of "Moderate" evaluation in an indoor experiment.

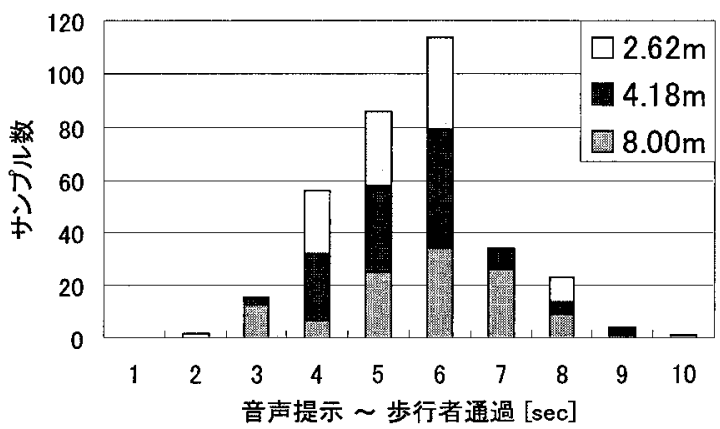

図 6 「適度」評価サンプルにおける警告提示から歩行者通過までの時間 の分布 (実験 1)

Fig.6 Distribution of the time from the warning presentation to the pedestrian passage (Experiment 1)

縌軸はサンプル数で, 横軸は音声提示から歩行者通過までの時間 を表している.これは同じ歩行者位置条件でも映像により若干変動 がある．そこで 1 秒台のデータは 1 秒， 2 秒台のデータは 2 秒とい うように分類した，前述のように，図6 は全て適度と回答されたデ 一タである。全体的に音声提示から 5 秒から 6 秒後に歩行者とすれ 違う条件汇集中している事が分かる.グラフ中の色の違いは歩行者 の位置の違いを表しており，歩行者の位置の違いにより分布特性が 大きく異なる傾向はない，以上の結果から，音声提示から歩行者の 脇を通過するまでの時間 5〜6 秒は, 適度評価を与える要因の 1 つ と考えられる。

図 7 に右折時の音声提示によるアクセル OFF 及びブレーキ ON 夕 イミングの変化を示す．縦軸は車が交差点に進入する直前を基準 0 秒とした場合のアクセルを離す時間とブレーキを踏む時間を表し ている. シンボルは各タアクセル OFF とブレーキ ON のタイミング の平均值で，棒洨標準偏差である.これより，音声提示を行らこと により早めのアクセル OFF，ブレーキ ON 確認することができた.

次に,フィールド実験におけ主観評価結果を図 8 に示す.フィ 一ルド実験では，交差点曲折時を正確に予測できないので，試行每 におおよその見当をつけて警告音声を提示した．従って室内実験と 違って音声提示タイミングは誧行ごとに異なる，そのため，全試行 にお计る音声提示時間の分布はつといで時間軸上に表している。そ の中で「適度」と回答された陚行での音声提示時閒をけで表してい る. 図 8 において, 上のグラフが右折時, 下のグラフが左折時の結 果を表している．右折では 1.5 秒から 3.5 秒，左折では 2 秒から 3 秒の範团に適度評価が集まっていることが分かる。

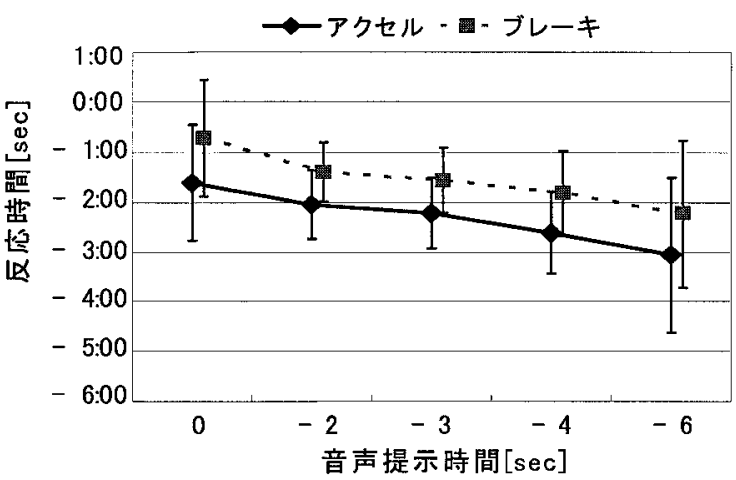

図 7 アクセルOFF・ブレーキONの時間虞移（右折時）

Fig.7 Transition of the time of accelerator-off and brake-on (in the case of the right turn).

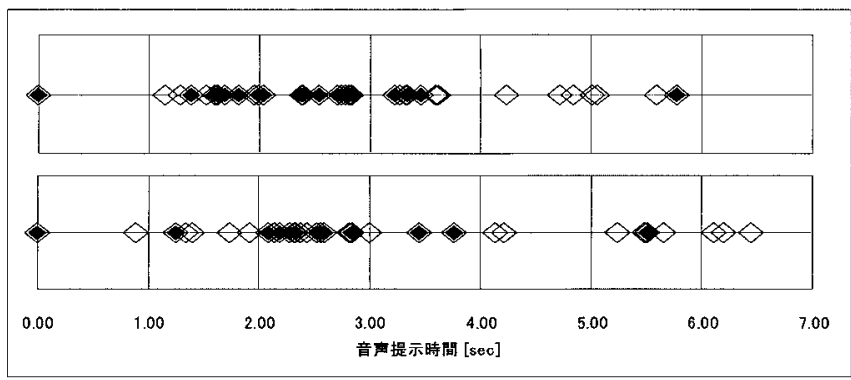

図 8 フィールド実験における「適度」評価および提示時間の分布 Fig.8 Results of the field experiment.

$\checkmark$ : "Moderate" evaluation

$\diamond$ : Distribution of presentation time of warning

右折左折を考慮すると 1.5 秒から 3.5 秒の問での音声提示の評 価の比率が最も高いことが分かる．前述のように歩行者の位置は 約 $4 \mathrm{~m}$ に固定したので，図 5 の $4.18 \mathrm{~m}$ が最も近い条件である. 室 内実験 と「適度」評価の提示時間が若干ずれた原因は現在のとこ ろ不明である.フィールド実験での被験者のほとんどが運転免許 は保持しているものの普段運転をしていないこと，また，電動ス クーターだということで，一般の乗用車で実際に運転する場合を 想定した室内実験に比べて, 制動距離が短く評価される傾向があ ったために值が大きい，才なわち音声提示のタイミングがわずか に遅いほうにシフトした可能性がある。

運転操作データでは，個人の運転特性が顕著に表れ図 7 のよう な音声提示による系統的な影響は見られなかった。

\section{4. 実験 2}

歩行者か自転車かという対象物の相違，交差点への進入速度の 違い，及びドライバーの性別差の影響を検討する実験を行った。

\section{1 実験}

実験 2 では撮影車両を普通自動車（以後，車と表記）に変えて, 撮影には正面と左右の視野用に 3 台のCCDカメラを使用し同期し て撮影した．大学のキャンパス内に進入路を $60 \mathrm{~m}$ ほど確保できる 見通しの悪い T 字路（図 9）を作成したＴ字路への進入速度を $20 \mathrm{~km} / \mathrm{h}$ と $30 \mathrm{~km} / \mathrm{h}$ の 2 パターン設定し, 自動車が右折又は左折し た途端に歩行者又は自転車を発見するという状況の映像を撮影 した，本が右折又は左折した直後の歩行者及び自転車の位置は， 交差点の端から右折時 $2 \sim 3 \mathrm{~m}$, 左折時 $3 \sim 4 \mathrm{~m}$ に固定した，各々の 
条件を実験用映像に編集し，3.1 と同様の実験装置を用いてスクリ ーン上に映像を投影する実験を行った。ここでは正面及び左右の 3 面に 3 台のプロジェクタで各々に対応する映像を同期して投影し た.「人が来ます」(約 0.5 秒）又は「自転車が来ます」(約 0.9 秒) という音声情報を, 車が交差点端点に進入する直前を基準 0 秒とし て, 0 秒〜 6 秒前の 7 種のタイミングで提示した. 映像の種類は対 象ありで 112 映像，対象なしで 8 映像，合計 120 映像を実験映像と して用いた。

被験者には映像に合わせて運転操作をするように指示し, 右折又 は左折して停止後, 音声情報のタイミングについて主観評価（遅い, やや遅い, 適度, やや早い, 早いを行ってもらった. 被験者は運 転免許保持の視力・聴覚正常な 20 代男性 9 名, 女性 9 名, 計 18 名 である. 各被験者において試行数は 120 回で, 1 セッション 10 映像 である．実験映像をランダムな順で組み合わせて提示した。

\section{2 結果}

図 10 (a)，(b) に男女別における「適度」評価の割合を示す，異 なる棒は曲がった直後の対象物 (人又は自転車) と車の進入速度の 違いを表している。横軸は車が交差点に進入する直前を基準として の音声提示時間を示している. 縦軸は, 各々の提示時間におるける全 回答数 36 試行に対する「適度」と評価された回答の割合である. この図から分かるように, 男性女性ともに対象物の違いや進入速度 の違いによる大きな差は見られず, 全条件において交差点直前より 3 秒前での音声情報提示の評価が高いといら結果が得られた。 しか し女性グループにおいては進入速度 $20 \mathrm{~km} / \mathrm{h}$ (遅) での「適度」評価 は男性グループ同様 3 秒前で高いのに対し, 進入速度 $30 \mathrm{~km} / \mathrm{h}$ （速） では 4 秒前での評価が男性よりも高いという結果となった. すなわ ち, 女性は男性よりも早めの警告においても「適度」と感じる傾向 があることが分かった。

図 11 (a)，(b) に実験 1 同様, 適度評価データにお打る音声提示 から対象を通過するまでの時閒の分布の男女別の結果を示す，縦軸 は適度評価のサンプル数, 横軸は音声提示から対象通過までの時間 を表し,グラフ中の色の違いは各条件別を表している. 全体的に音 声提示から 4 秒台から 5 秒台に歩行者又は自転車とすれ違う状況で の評価が高い事が分かる. 特に女性に関しては 5 秒台での評価の割 合が高くなっている.

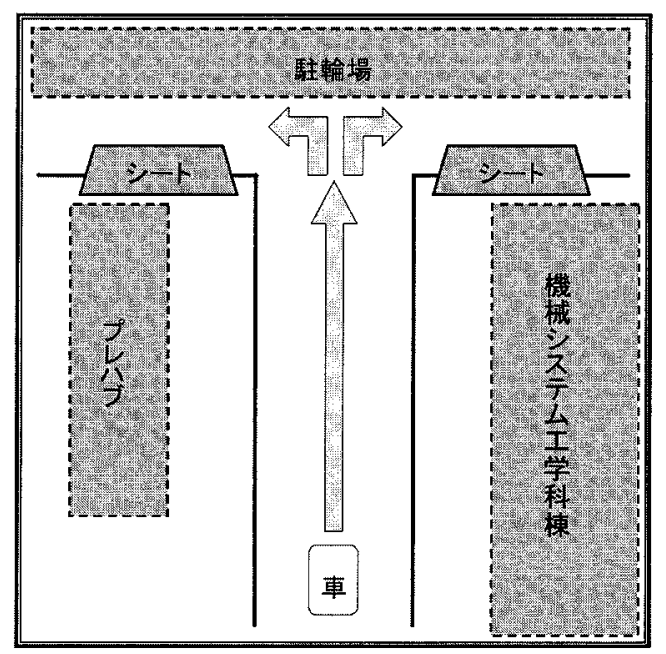

図 9 実験 2 における撮影場所

Fig.9 Filming place for experiment 2.
運転操作についても調べたが，この実験では大きな差は見られ なかった. 歩行者の位置を一定にしたため実験映像への慣れが生 じた可能性がある。

(a) 男性

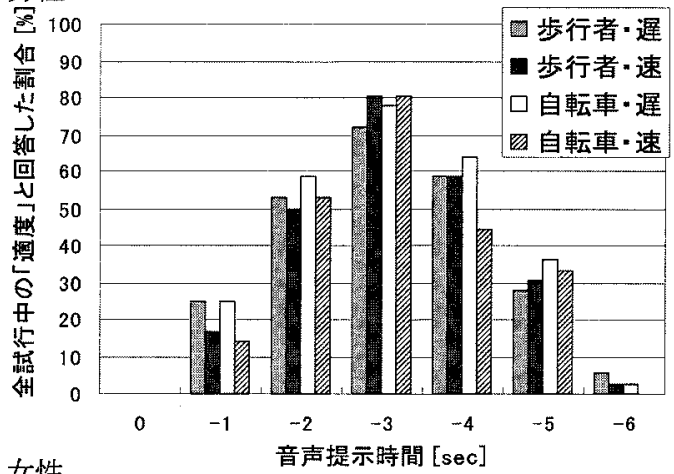

(b) 女性

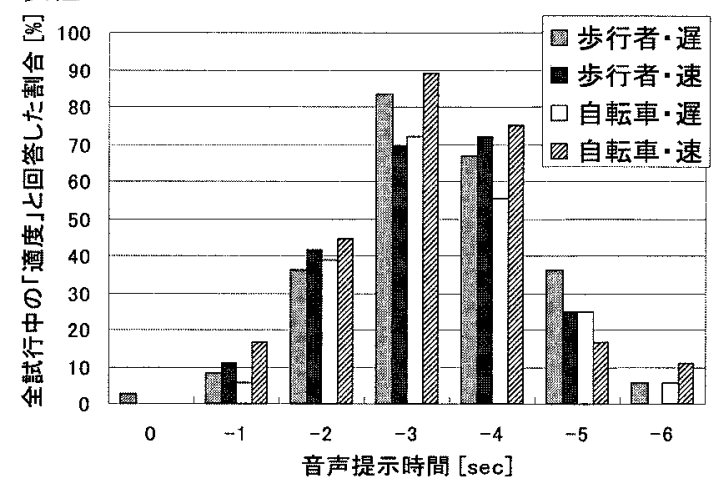

図 10 室内実験における「適度」評価の分布

Fig.10 Results of "Moderate" evaluation in an indoor experiment.

（a）男性

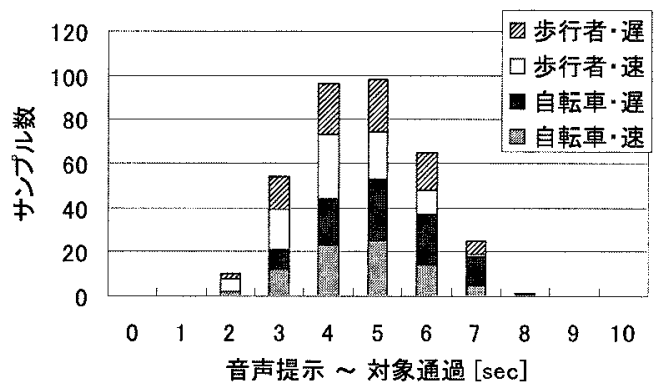

(b) 女性

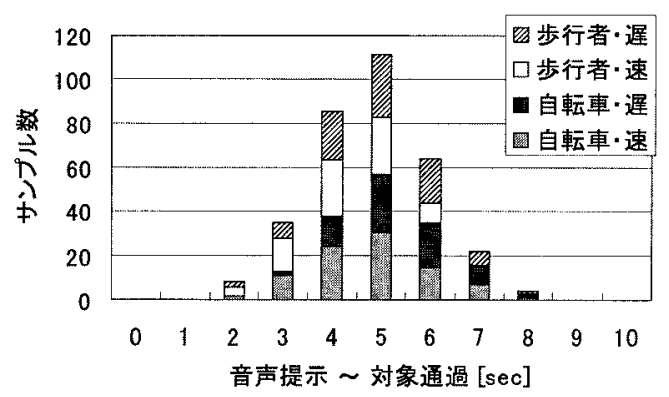

図 11 「適度」評洒サンプルにおける警告提示から対象通過までの時間 の分布 (実験 2)

Fig.11 Distribution of the time from the warning presentation to the pedestrian passage (Experiment 2). 


\section{5. おわりに}

今回の研究では，見通しの悪い交差点で音声によりドライバーに 警告を与えるシステムを想定し，被験者の主観評価と運転操作デー 夕を基に適切な音声提示時間を検討した。

実験 1 では交差点からの歩行者の位置を 3 パターン設定し，それ ぞれの「適度」評価のピークの推移状況を確認することができ，そ こから被験者の適度評価判断には, 音声提示から歩行者の脇を通過 するまでの時閒が重要であるという所見が得られた．また，音声提 示による運転操作の変化も確認することができた．すなわち，出会 い頭か，曲折後ゆとりをもってすれ違うかという交差点進入後の対 象物との距離により，交差点進入前の警告提示の最適タイミングが 異なる結果であり，図 1 に示すような探知警告システムの必要性が 示唆された.

実験 2 では交差点での対象物と進入速度をそれぞれ 2 パターン設 定して実験を行った. 男性と女性グループでの結果と比較したとこ ろ，平均值では統計的な差はなかったが，図 10 に見られる分布の 形状から男女差が現れることが確認できた.

この 2 つの実験より，ドライバーへの音声警告システムの設計に は, 車の交差点への進入速度, 歩行者や自転車の交差点からの距離, さらに運転者の性差も考慮すべき要因であることが示された.

今後の課題としては, 歩行者の出現位置の条件の追加, 対向車の 有無, 昼夜などの環境の変化, 交差点の種類, 視覚的情報提示方法 との比較などの検討が必要である.

本研究の一部は平成 12 年度国際コミュニケーション基金調査 研究助成により行われた。記して謝意を表する。

\section{参考文献}

（1）平成 15 年度版交通安全白書 http://www8.cao.go.jp/koutu/taisaku/index-thtml

（2）赤松幹之，渥美文治：ITS 時代のドライバーを取り巻く情報とヒュ ーマンインターフェース,自動車技術,Vol.55，No.11，pp.47-52 (2001).

（3）宇野宏，麻生勤，新谷研二：文字ならびに地図情報の取得時間に 関する基礎的検討，自動車研究，Vol.22，No.10，pp.29-32 (2000).

(4) Hirst,S. and Graham,R. :The Format and Presentation of Collision Warnings, Ergonomics \& Safety of Intelligent Driver Interface, pp.203-219 (1997).

(5) Dingus, T.A. Hulse,M.C. Mollenhauer,M.A. Fleischman,R.N. Mcgehee,D.V. and Manakkal,N. : "Effects of age, system experience, and navigation technique on driving with advanced traveler information system", Human Factors, 39, pp.177-199 (1997).

(6) Ihata,N. Ikegami,M. Kawaguchi,M. Hasegawa,H. Ayama,M. and Kasuga,M. : Reaction time of the secondary task while driving in various situations, Proceedings of the 5th Annual IEEE ITSC, Singapole, CD-ROM (2002).

(7) Ayama,M. Hasegawa,H. Kawaguchi,M. Ihata,N. Ikegami,M. and Kasuga,M. : A study to measure spare capacity of driver's attention payable to cognitive subtask, Proceedings of the 5th Annual IEEE ITSC, Singapole, CD-ROM (2002).

(8) Yamaguchi,T. Matsuda,S. Ohashi,K. Tamai,I. Ayama,M. and Harashima,F. :Human automotive system using driver and pedestrian intention recognition, Proceedings of the 11 th World Congress on ITS, CD-ROM (2004).

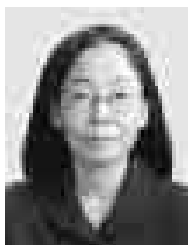

阿山 みよし（専門会員）

宇都宮大学大学院工学研究科情報制御システム 科学専攻

干 321-8585 宇都宮市陽東 7・1-2

1954 年 4 月 10 日生まれ。 1983 年東京工業大学 大学院総合理工学研究科物理情報工学専攻博士 後期課程修了. 宇都宮大学工学部助教授を経て現 在大学院工学研究科教授. 工学博士. 視覚情報処理, 色彩科学, 視聴覚相互作用, 自動車運転者の視鸴認知特性の研究と教育に従 事. 照明学会, 日本照明委員会, 日本視覚学会, 応用物理学会, 日本光学会, 日本色彩学会, 映像情報メディア学会会員.

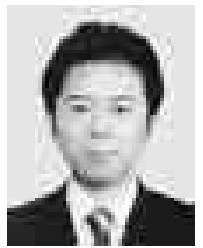

加藤 崇史 (非会員)

1980 年 4 月 10 日生まれ. 2003 年宇都宮大学情 報工学科卒業. 2003 年同大学大学院工学研究科 情報制御システム科学専攻博士前期課程在学中.

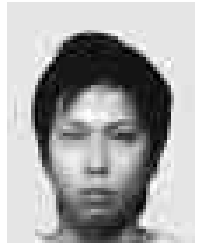

漆畑 直紀 (非会員)

1978 年 8 月 2 日生まれ。 2002 年 宇都宮大学情 報工学科卒業. 2004 年同大学大学院工学研究科 情報工学専攻修士課程修了. 2004 年株式会社 小 糸製作所に入社，現在に至る.

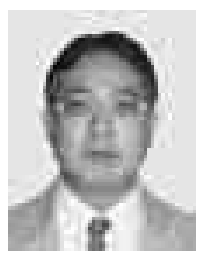

\section{山口＼cjkstart亨（非会員）}

1956 年 8 月 25 日生まれ. 1981 年千葉大学院工 学研究科電気工学専攻修士課程修了. 1981 年 4 月（株）東芝入社. 1989 年技術研究組合国際フ アジィ工学研究所へ出向. 1992 年 (株) 東芝シ ステム・ソフトウェア技術研究所. 1993 年宇都 宮大学情報工学科助教授. 2000 年東京都立科学技術大学電子シ ステム工学科教授，現在に至る.ファジィとニューラルネットに 関する研究に従事. 計測自動制御学会, 電気学会, 日本知能情報 ファジィ学会, 日本神経回路網学会, 日本ロボット学会各会員.

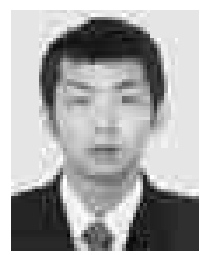

大橋 邦博 (非会員)

1980 年 5 月 21 日生まれ. 2003 年 東京都立科学 技術大学電子システム工学科卒業. 2003 年同大 学大学院工学研究科システム基礎博士前期課程 在学中. 